\title{
VITAMIN D DEFICIENCY DID NOT AUGMENT THE PROGRESSION OF HIGH-FRUCTOSE-INDUCED NONALCOHOLIC FATTY LIVER DISEASE IN RATS
}

\author{
VITAMIN D EKSIKLIĞi SIÇANLARDA ALKOLE BAĞLI OLMAYAN YAĞLI KARACIĞER \\ HASTALIĞININ PROGRESYONUNU ARTTIRMADI
}

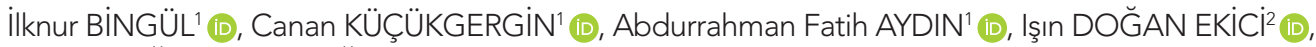 \\ Semra DOĞRU ABBASOĞLU1 (D), Müjdat UYSAL' (1) \\ I'stanbul University, Istanbul Faculty of Medicine, Department of Medical Biochemistry, Istanbul, Turkey \\ ${ }^{2}$ Acibadem Mehmet Ali Aydınlar University, Acibadem University Medical Faculty, Department of Pathology, Istanbul, Turkey
}

ORCID IDs of the authors: i.B. 0000-0002-6432-3541; C.K. 0000-0002-1797-5889; A.F.A. 0000-0002-3336-4332; I.D.E. 0000-0003-4062-9519; S.D.A. 0000-0003-3467-9763; M.U. 0000-0002-8802-8766

Cite this article as: Bingul I, Kucukgergin C, Aydin AF, Dogan Ekinci I, Dogru Abbasoglu S, Uysal M. Vitamin D deficiency did not augment the progression of high-fructose-induced nonalcoholic fatty liver disease in rats. J Ist Faculty Med 2021;84(3):360-9. doi: 10.26650/IUITFD.2021.849531

\section{ABSTRACT}

Objective: Vitamin D has antioxidant, anti-inflammatory and antiglycation activities, and hepatoprotective potential. There is a relationship between vitamin D deficiency (VDD) and the severity of liver disorders. VDD has been proposed to contribute to the progression of nonalcoholic fatty liver disease (NAFLD). However, experimental results are not clear. Therefore, in this study, the effects of a VDD diet on high fructose (HFr) drinking-induced NAFLD was evaluated.

Material and Method: Male Wistar rats were divided into four groups as control, HFr, VDD+HFr, and VDD. Control and $\mathrm{HFr}$ groups were fed a control diet, and other groups with a VDD-diet for 12 weeks. $\mathrm{HFr}$ (30\%; w/v; in drinking water) was given in the last 8 weeks. Insulin resistance (IR), serum lipids, hepatic triglyceride, lipid peroxide, protein carbonyl, advanced glycation end products (AGEs) and inflammation (TNF- $\alpha$ and myeloperoxidase) parameters, and histopathological changes were investigated.

Results: Increases in serum transaminases, hypertriglyceridemia, and IR were observed in HFr and VDD+HFr groups. Increased liver triglyceride, lipid and protein oxidation products, protein glycation and inflammation markers as well as microvesicular hepatic steatosis and hepatocyte ballooning were observed in both groups. Although IR and hepatic inflammation markers were higher in the VDD+HFr group, serum transaminases, hepatic triglyceride, lipid and protein oxidation products, and glycation indicators in the liver did not alter between the two groups. However, Nrf2 mRNA expression and superoxide dismutase and

\section{ÖZET}

Amaç: Vitamin D antioksidan, antiinflamatuvar ve antiglikasyon etkinliğe ve karaciğeri koruyucu potansiyele sahiptir. Vitamin D eksikliği/yetersizliği (VDD/NDI) ile karaciğer bozukluklarının ciddiyeti arasında bir ilişki bulunmaktadır. VDD'nin alkole bağlı olmayan yağlı karaciğer hastalığının (NAFLD) progresyonunda etkili olduğu bildirilmiştir. Fakat deneysel sonuçlar yeterli değildir. Bu nedenle, bu çalışmada VDD'nin yüksek fruktozlu (HFr) içme suyu uygulanarak oluşturulan NAFLD üzerine etkisi incelendi.

Gereç ve Yöntemler: Erkek Wistar sıçanlar kontrol, HFr, VDD+Fr ve VDD olmak üzere 4 gruba ayrıldı. Kontrol ve HFr grupları Vit $\mathrm{D} 3$ içeren, diğerleri ise Vit $\mathrm{D}_{3}$ içermeyen yemle 12 hafta beslendiler. HFr (\%30; w/v) içme suyu ile son 8 hafta uygulandı. Insulin direnci (IR), serum lipitleri, hepatik trigliserit, lipit peroksit, protein karbonil, ileri glikasyon ürünleri (AGEs) ve inflamasyon (TNF- $\alpha$ ve miyeloperoksidaz) göstergeleri tayin edildi.

Bulgular: HFR ve VDD+HFr gruplarında serumda transaminazlar arttı, hipertrigliseridemi, ve insülin direnci oluştu. Her iki grupta da karaciğerde trigliserit düzeyleri, lipit ve protein oksidasyon ürünleri, protein glikasyon ve inflamasyon göstergeleri arttı, mikroveziküler steatoz ve hepatosit balonlaşması saptandı. IR ve inflamasyon göstergeleri VDD+HFr grubunda daha yüksek olmasına rağmen, iki grup arasında serum transaminazları, karaciğer trigliserit, lipit ve protein oksidasyon ürünleri ve glikasyon göstergeleri düzeylerinde bir farklılık bulunmadı. Ancak Nrf2 mRNA ekspresyonu ile süperoksit dismutaz ve glutatyon peroksidazın mRNA ekspresyonları ve aktivitelerinin VDD+HFr grubunda

Corresponding author/iletişim kurulacak yazar: ilknur.bingul@istanbul.edu.tr

Submitted/Başvuru: 29.12.2020 • Accepted/Kabul: 16.04.2021 • Published Online/Online Yayın: 14.07.2021 
glutathione peroxidase mRNA expression and activities were significantly higher in the VDD+HFr group.

Conclusion: Our results show that VDD did not augmented HFr-induced hepatotoxicity and glycooxidative stress in the liver of rats.

Keywords: Vitamin D deficiency, high fructose diet, nonalcoholic liver disease, glycooxidative stress, antioxidant, inflammation daha yüksek olduğu bulundu.

Sonuç: Sonuçlarımız VDD'nin HFr ile oluşturulan karaciğer hasarı ve glikooksidatif streste bir değişiklik oluşturmadığını göstermektedir.

Anahtar Kelimeler: Vitamin D yetersizliği, yüksek fruktozlu diyet, alkolik olmayan karaciğer hastalığı, glikooksidatif stres, antioksidanlar, inflamasyon

\section{INTRODUCTION}

Nonalcoholic fatty liver disease (NAFLD) refers to an accumulation of fat in the liver due to causes other than alcohol. NAFLD is accepted as the hepatic manifestation of the metabolic syndrome. NAFLD starts with simple steatosis and it can progress to more serious conditions, such as steatohepatitis (NASH), fibrosis and cirrhosis. According to a two-hit hypothesis, the presence of steatosis (first hit) makes the liver susceptible to some factors such as oxidative stress, endotoxemia, inflammation and mitochondrial dysfunction as the second hit (1). Advanced glycation end products (AGEs) also play an important role as a contributing factor in the pathogenesis of NAFLD (2).

A high-fructose (HFr) diet affects glucose and lipid metabolism and causes various metabolic disorders such as insulin resistance (IR), hypertriglyceridemia and NAFLD (3). A HFr diet is one of the good dietary models of NAFLD in animals (4). Increased lipogenesis, oxidative stress and inflammation, and decreased $\beta$-oxidation are strongly associated with HFr-induced NAFLD (5). Increases in non-enzymatic protein glycation result in the accumulation of advanced glycation end products (AGEs) in $\mathrm{HFr}$ rats (6). These products are known to affect structures and functions of proteins and cause further increased oxidative stress and inflammation by interacting with their receptors $(2,6)$. Therefore, AGEs were accepted to be effective in the progression of NAFLD (6).

There are two main forms of Vitamin D: Vit $D_{2}$ (ergocalciferol) and $V$ it $D_{3}$ (cholecalciferol). Vit $D_{2}$ is derived from the diet, but Vit $D_{3}$ is both derived from diet and synthesized from 7-dehydrocholesterol with the effect of ultraviolet light on the human skin. Dietary or synthesized Vit D are hydroxylated in the liver to 25-hydroxyvitamin $D[25(\mathrm{OH})$ $D]$. It is subsequently hydroxylated in the kidney into 1,25-dihydroxyvitamin $\mathrm{D}\left[1,25(\mathrm{OH})_{2} \mathrm{D}\right]$ which is the biologically active form of Vit $D(7)$.

$1,25(\mathrm{OH})_{2} \mathrm{D}$ induces biological effects by binding to a vitamin D receptor (VDR) located in the nucleus of target cells. Its classical role is in calcium/phosphate homeostasis. Additionally, it has multiple functions and target organs and influences the expression of several genes and plays important roles in the regulation of cell proliferation and differentiation, immune function, oxidative stress, protein glycation, inflammation, and apoptosis (7-9). Therefore, Vit $D$ has been reported to be effective in preventing many diseases such as diabetes, hypertension, cardiovascular and hepatic diseases and cancer (10-12).

Vit $\mathrm{D}$ deficiency (VDD) is quite common in the world. Sedentary lifestyle, inadequate sunlight exposure and the lack of Vit $D$ in the food has resulted in $\operatorname{VDD}(13,14)$. Serum 25(OH)D levels are used as an indicator of Vit $D$ stores. Although there are some differences in clinical guidelines, the Institute of Medicine (Washington; USA) defines VDD as a 25(OH)D level of $<20 \mathrm{ng} / \mathrm{mL}$ and severe VDD as $<10 \mathrm{ng} / \mathrm{mL}$ (15). VDD alone may induce IR, oxidative stress, inflammation, and mitochondrial dysfunction $(8,10,14)$. However, epidemiological and laboratory evidence have shown that VDD may be associated with some common diseases such as tumors, bone diseases, immune disorders, cardiovascular diseases, diabetes mellitus, and chronic liver disorders (12-14). VDD has also been reported to be a secondary factor in the onset and progression of NAFLD, but a clear result has not been reached in clinical and experimental studies $(7,10,11,16,17)$.

In this study, we aimed to examine whether a diet deficient in $\mathrm{Vit}_{3}$ has a progressive effect on HFr-induced NAFLD in rats. For this reason, parameters affecting the progression of NAFLD such as IR, hepatic prooxidant and antioxidant parameters, protein glycation and inflammation markers together with histopathological changes were evaluated in the liver.

\section{MATERIAL AND METHOD}

\section{Chemicals}

Fructose $(\mathrm{Fr})$ and other chemicals were purchased from Sigma-Aldrich (Saint-Louise, MI, USA).

\section{Animals}

Male Wistar rats (140-160 g) were provided from the Aziz Sancar Experimental Medical Research Institute of Istanbul University. The animals were supplied with food and water ad libitum. They were kept in polypropylene cages (three to four per cage) at $22^{\circ} \mathrm{C}$, with 12 -h light and 12 -h darkness without shielding from ultraviolet $\mathrm{B}$ radiation (290-320 mn). 


\section{Diets and experimental design}

Rats were randomly assigned into four groups as control $(n=6), \operatorname{HFr}(n=7), \mathrm{HFr}+\operatorname{VDD}(n=8)$ and VDD $(n=8)$ groups. Control and HFr groups were fed on PicoLab Rodent diet 5053 (2300 IU Vit D3/kg added); however, VDD+HFr and VDD groups were fed on Modified LabDiet 5053 (Vit D3 not added) for 12 weeks. These diets were supplied from LabDiet (St. Louis-Missouri, USA). Fructose $(30 \%$, w/v) was added to drinking water for the last 8 weeks to $\mathrm{HFr}$ and VDD+HFr groups.

\section{Samples}

The animals were fasted overnight and anesthetized with ketamine $(35 \mathrm{mg} / \mathrm{kg}$, i.p., Pfizer, USA) and xylazine $\mathrm{HCl}(15$ $\mathrm{mg} / \mathrm{kg}$, i.p., Bioveta, Czech Republic). Blood was collected into dry tubes by cardiac puncture and centrifuged at $1,500 x g$ for 10 min to get serum.

Liver tissues were removed, washed with ice-cold 0.9\% $\mathrm{NaCl}$ and homogenized in ice-cold PBS (phosphate-buffered saline; $0.01 \mathrm{M}, \mathrm{pH}: 7.4$ ). Liver homogenates were centrifuged at $600 \mathrm{~g}$ for $10 \mathrm{~min}$ at $4^{\circ} \mathrm{C}$ to obtained the postnuclear fraction (PNF). Serum and postnuclear fraction of liver were stored at $-80^{\circ} \mathrm{C}$ until they were analyzed. The liver index was calculated as liver weight /body weightx100.

\section{Determinations in serum}

Serum fasting glucose, triglyceride (TG), calcium and inorganic phosphorus levels, and alanine aminotransferase (ALT) and aspartate aminotransferase (AST) activities were measured using a Cobas Integra 800 autoanalyzer (Roche Diagnostics, Mannheim, Germany). Serum $25(\mathrm{OH}) \mathrm{D}_{3}$ and insulin levels were determined by ELISA kits (Abbkine, Wuhan-China). Homeostasis model assessment (HOMA) index was used to evaluate insulin resistance (IR) and calculated using the formula: fasting insulin concentration (pmol/L)xfasting glucose concentration (mmol/L)/135. High HOMA scores indicate IR (low insulin sensitivity).

\section{Determinations in the liver}

TG, hydroxyproline (Hyp), tumor necrosis factor-alfa (TNF- $\alpha$ ) levels and myeloperoxidase (MPO) activity

TG levels were determined in hepatic lipid extracts by using kits provided by Biolabo Biochemistry and Coagulation (Maizy, France). Liver tissues were homogenized in 10 volumes of PBS with a glass homogenizer on ice. Tissue homogenates were sonicated, and then centrifuged at $5,000 \mathrm{~g}$ for $5 \mathrm{~min}$ to get the supernatants. Hyp (Bioassay Technology Laboratory, Shanghai, China) and TNF- $\alpha$ (USCN, Wuhan, China) levels were determined in these supernatants by using ELISA kits.

To determine MPO activity, liver tissue was homogenized in $0.5 \%$ hexadecyltrimethylamine bromide in 50 $\mathrm{mM}$ phosphate buffer, $\mathrm{pH}$ 6. The homogenates were sonicated, freeze-thawed three times and centrifuged at $10,000 \times$. MPO activity was measured in the supernatant samples (18).

\section{Hepatic reactive oxygen species (ROS), lipid peroxide and protein oxidation products}

ROS generation was determined by the method described by Wang and Joseph (19). After excitation at 485 $\mathrm{nm}$, the fluorescence emission of $2^{\prime}, 7^{\prime}$-dichlorofluorescein at $538 \mathrm{~nm}$ was recorded using a microplate fluorometer and luminometer (Fluoroskan Ascent FL, Thermo Scientific Inc, USA).

Thiobarbituric acid reactive substances (TBARS) and diene conjugate (DC) levels were measured to assess hepatic lipid peroxidation. TBARS levels were determined according to Buege and Aust and calculated from absorption at $532 \mathrm{~nm}$ by using the molar extinction coefficient of $1.56 \times 10^{5} \mathrm{M}^{-1}(20)$. DC levels were determined spectrophotometrically at $233 \mathrm{~nm}$. For this assay, liver lipids were extracted in chloroform/methanol $(2: 1 ; \mathrm{v} / \mathrm{v})$ mixture, and then the extracted lipids were dissolved in cyclohexane. DC levels were calculated using a molar extinction coefficient of $2.52 \times 10^{4} \mathrm{M}^{-1} \mathrm{~cm}^{-1}(20)$.

PC levels were evaluated according to the method of Reznick and Packer, which is based on the measurement of protein hydrazones (21). Results were calculated from the maximum absorbance $(360 \mathrm{~nm})$ using a molar extinction coefficient of $22,000 \mathrm{M}^{-1} \mathrm{~cm}^{-1}$.

\section{Protein glycation products in liver and serum}

Hepatic advanced oxidation products of protein (AOPP) levels were measured spectrophotometrically at $340 \mathrm{~nm}$ (22). AGEs levels were determined spectrofluometrically in the liver and serum. For this reason, liver homogenates or serum were diluted with PBS (pH 7.4) and the fluorescence intensity $\left(\lambda_{\text {emission}}: 440 \mathrm{~nm}\right.$; $\left.\lambda_{\text {excitation }}: 350 \mathrm{~nm}\right)$ was determined (23). $N^{\varepsilon}$-(carboxymethyl)lysine (CML) levels were measured using ELISA kits (Abbkine, Wuhan, China).

\section{Determination of antioxidant system parameters} Hepatic ferric reducing anti-oxidant power (FRAP) levels were determined spectrophotometrically to evaluate antioxidant power in liver. Reducing a ferric-tripyridyltriazine complex to the ferrous form by the antioxidants in liver homogenates is monitored by measuring the change in absorption at $593 \mathrm{~nm}$ (24). Hepatic glutathione (GSH) levels were determined by using 5,5-dithiobis-(2-nitrobenzoate) at $412 \mathrm{~nm}$ (25).

Superoxide dismutase (SOD) activity was determined according to Mylorie et al., and calculated using a standard curve prepared by bovine SOD (26). Glutathione peroxidase (GSH-Px) activity was measured using cumene hydroperoxide as a substrate (27). The reaction was followed spectrophotometrically (340 nm) at $37^{\circ} \mathrm{C}$, and ac- 
tivity was calculated using the extinction coefficient of NADPH $\left(6.22 \times 10^{3} \mathrm{M}^{-1} \mathrm{~cm}^{-1}\right)$. Catalase (CAT) activity was measured spectrophotometrically at $240 \mathrm{~nm}$ by using hydrogen peroxide $\left(\mathrm{H}_{2} \mathrm{O}_{2}\right)$ as substrate (28). One unit of CAT was considered as the activity of enzyme needed to degrade $1 \mu \mathrm{mol} \mathrm{H}_{2} \mathrm{O}_{2}$ per min at $25^{\circ} \mathrm{C}$.

Determination of mRNA expressions of nuclear erythroid factor 2-related factor (Nrf2) superoxide dismutase (SOD), glutathione peroxidase (GSH-Px) and catalase (CAT)

In order to obtain mRNA expressions of Nrf2, SOD, GSH-Px and CAT in liver, the tissue was homogenized using a handheld homogenizer (SCILOGEX D160, USA). Total RNA was isolated using an RNA isolation kit (NucleoSpin RNA Kit, \#740955, Macherey-Nagel, Germany). cDNA was synthesized with a SCRIPT cDNA Synthesis Kit (Jena Bioscience, GmbH, Jena, Germany) by using 5 ng RNA. Nrf2 (F: 5'-GTGGATCTGTCAGCTACTCCC-3'; R: 5'-CTGGGAATATCCAGGGCAAGC-3'), SOD (F: 5'-GGTCCAGCGGATGAAGAG-3'; R: 5'-GGACACATTGGCCACACC-3'), GSH-PX (F: 5'-CGACATCGAACCCGATATAGA-3'; R: 5'-ATGCCTTAGGGGTTGCTAGG-3'), CAT (F: 5'-AGGTGCTTTTGGATACTTTGAGG-3'; R: 5'-CGACTGTGGAGAATCGGACGG-3') primers, and the housekeeping gene GAPDH (F: 5'-CAGGGCTGCCTTCTCTTGTG-3'; R: 5'-AACTTGCCGTGGGTAGAGTC-3') were purchased from LGC Biosearch Technologies (Denmark). Quantitative real-time polymerase chain reaction ( $q P C R$ ) was performed using QPCR Green Master with UNG (Jena Bioscience, GmbH, Jena, Germany) in a real-time PCR system (Biorad CFX Connect, California, USA). The expression levels of mRNAs were quantified using the 2 $-\Delta \Delta C t$ method.

\section{Protein levels}

Protein levels were determined spectrophotometrically using bicinchoninic acid (29).

\section{Histopathologic examination}

Livers were fixed in 10\% buffered formalin, embedded in paraffin, sectioned and stained with hematoxylin and eosin (H\&E) for histologic examinations. Masson's trichrome (MTC) staining was also performed to show reticulin fibers of fibrotic areas. Steatosis, liver damage and fibrosis scores were made according to the protocol proposed by Goodman, as previously described in detail in our previous study $(30,31)$.

\section{Statistical analysis}

Statistical analysis was evaluated by using the Statistical Package for The Social Sciences program (21.0; SPSS Inc., Chicago, IL, USA) program. All variables were expressed as mean \pm standard deviation (SD). Data distributions and test of normality were investigated by Kolmogorov-Smirnov test. One-way ANOVA test (post-hoc Tukey's test) was used to assess the parameters with normal distribution. Homogeneity of variances was evaluated with Levene test. Kruskal-Wallis test (post-hoc Mann Whitney-U test) was used to compare the parameters without normal distribution. In all cases, a difference was considered significant when $\mathrm{p}<0.05$.

\section{RESULTS}

Final body weight did not change, but liver weight and liver index were elevated in $\mathrm{HFr}$ and $\mathrm{VDD}+\mathrm{HFr}$ groups as compared to control group. Serum $25(\mathrm{OH}) \mathrm{D}_{3}$ levels did not alter in the HFr group, but it decreased (47.3\%) in the VDD+HFr group. Calcium and inorganic phosphorus levels remained unchanged in both groups as compared to the control (Table 1).

Significant increases in glucose, TG and HOMA levels, ALT and AST activities were detected in the HFr and VDD+HFr groups as compared to the control. However, insulin levels remained unchanged in both groups. Glucose and HOMA levels were higher in the VDD+HFr group than the HFr group (Table 2).

Table 1: The effect of vitamin D deficiency (VDD) on body weight, liver weight, and liver index ${ }^{*}$ values and serum levels of 25(OH)D3, calcium, and phosphorus in high fructose (HFr)-treated rats (Mean \pm SD)

\begin{tabular}{lcccc}
\hline & $\begin{array}{c}\text { Control } \\
(\mathbf{n}=6)\end{array}$ & $\begin{array}{c}\text { VDD } \\
(\mathbf{n}=\mathbf{8})\end{array}$ & $\begin{array}{c}\text { HFr } \\
(\mathbf{n}=\mathbf{7})\end{array}$ & $\begin{array}{c}\text { VDD+HFr } \\
(\mathbf{n}=\mathbf{8})\end{array}$ \\
Body weight $(\mathrm{g})$ & $299.5 \pm 16.1$ & $315.5 \pm 29.8$ & $312.1 \pm 31.5$ & $336 \pm 16.5$ \\
Liver weight $(\mathrm{g})$ & $8.25 \pm 0.93$ & $7.55 \pm 0.70$ & $10.3 \pm 1.46^{\mathrm{a} 2}$ & $10.9 \pm 0.83^{\mathrm{a} 1}$ \\
Liver index $(\%)$ & $2.75 \pm 0.21$ & $2.41 \pm 0.36$ & $3.28 \pm 0.27^{\mathrm{a} 2}$ & $3.22 \pm 0.21^{\mathrm{a} 3}$ \\
$25(\mathrm{OH}) \mathrm{D}_{3}(\mathrm{ng} / \mathrm{mL})$ & $28.4 \pm 3.09$ & $15.7 \pm 1.07^{\mathrm{a} 2}$ & $25.3 \pm 5.88$ & $15.0 \pm 1.51^{\mathrm{a} 2,61}$ \\
Calcium $(\mathrm{mmol} / \mathrm{L})$ & $2.42 \pm 0.16$ & $2.50 \pm 0.18$ & $2.36 \pm 0.12$ & $2.39 \pm 0.15$ \\
Phosphorus $(\mathrm{mmol} / \mathrm{L})$ & $2.55 \pm 0.18$ & $2.58 \pm 0.26$ & $2.30 \pm 0.16$ & $2.40 \pm 0.29$ \\
\hline
\end{tabular}

${ }^{a} 1 \mathrm{p}<0.001,{ }^{a} \mathrm{p}<0.01,{ }^{a} \mathrm{p}<0.05$ as compared to control; ${ }^{b 1} \mathrm{p}<0.001 \mathrm{HFr}$ vs $\mathrm{VDD}+\mathrm{HFr}$

*Liver index= Liver weightx100/body weight 
Table 2: The effect of vitamin D deficiency (VDD) on some biochemical parameters in serum of high fructose $(\mathrm{HFr})$-treated rats. (Mean $\pm \mathrm{SD})$

\begin{tabular}{lcccc}
\hline & $\begin{array}{c}\text { Control } \\
(\mathbf{n}=6)\end{array}$ & $\begin{array}{c}\text { VDD } \\
(\mathbf{n}=\mathbf{8})\end{array}$ & $\begin{array}{c}\mathrm{HFr} \\
(\mathbf{n}=\mathbf{7})\end{array}$ & $\begin{array}{c}\text { VDD+HFr } \\
(\mathbf{n}=\mathbf{8})\end{array}$ \\
Glucose $(\mathrm{mmol} / \mathrm{L})$ & $7.53 \pm 1.44$ & $9.76 \pm 1.04^{\mathrm{a} 3}$ & $12.2 \pm 1.09^{\mathrm{a} 1}$ & $14.3 \pm 1.67^{\mathrm{a} 1,63}$ \\
Insulin $(\mathrm{mmol} / \mathrm{L})$ & $29.2 \pm 4.37$ & $29.3 \pm 2.98$ & $24.5 \pm 2.01$ & $27.9 \pm 5.29$ \\
HOMA-IR & $1.61 \pm 0.33$ & $2.10 \pm 0.21^{\mathrm{a} 2}$ & $2.21 \pm 0.23^{\mathrm{a} 2}$ & $2.96 \pm 0.68^{\mathrm{a} 2, \mathrm{~b} 3}$ \\
$\mathrm{TG}(\mathrm{mmol} / \mathrm{L})$ & $0.48 \pm 0.09$ & $1.13 \pm 0.26^{\mathrm{a} 2}$ & $0.79 \pm 0.18^{\mathrm{a} 2}$ & $0.71 \pm 0.05^{\mathrm{a} 3}$ \\
ALT $(\mathrm{U} / \mathrm{L})$ & $43.3 \pm 13.1$ & $53.6 \pm 8.53$ & $58.0 \pm 4.86^{\mathrm{a} 3}$ & $67.9 \pm 10.3^{\mathrm{a} 1}$ \\
AST $(\mathrm{U} / \mathrm{L})$ & $108.0 \pm 10.2$ & $114.6 \pm 19.0$ & $139.6 \pm 22.1^{\mathrm{a} 2}$ & $148.8 \pm 27.1^{\mathrm{a} 2}$ \\
\hline
\end{tabular}

${ }^{a 1} p<0.001,{ }^{a 2} p<0.01,{ }^{a 3} p<0.05$ as compared to control; ${ }^{b 3} p<0.05$ HFr vs VDD $+H F r$

In hematoxylin and eosin (H\&E) and Masson's trichrome (MTC) staining of liver sections, the HFr group exhibited marked microvesicular steatosis and hepatocyte ballooning without fibrotic changes. Some alleviations in histopathological findings were obtained in the VDD+HFr group (Figure 1). Steatosis score decreased significantly in the VDD+HFr (1.63 \pm 0.52$)$ group as compared to $\mathrm{HFr}(3.00 \pm 0.00)$. However, the ballooning score did not change significantly in the VDD+HFr (1.63 \pm 0.52$)$ as compared to $\mathrm{HFr}(2.00 \pm 0.00)$ group.

Hepatic TG and TNF- $\alpha$ levels and MPO activity were elevated, but Hyp levels remained unchanged in the HFr and
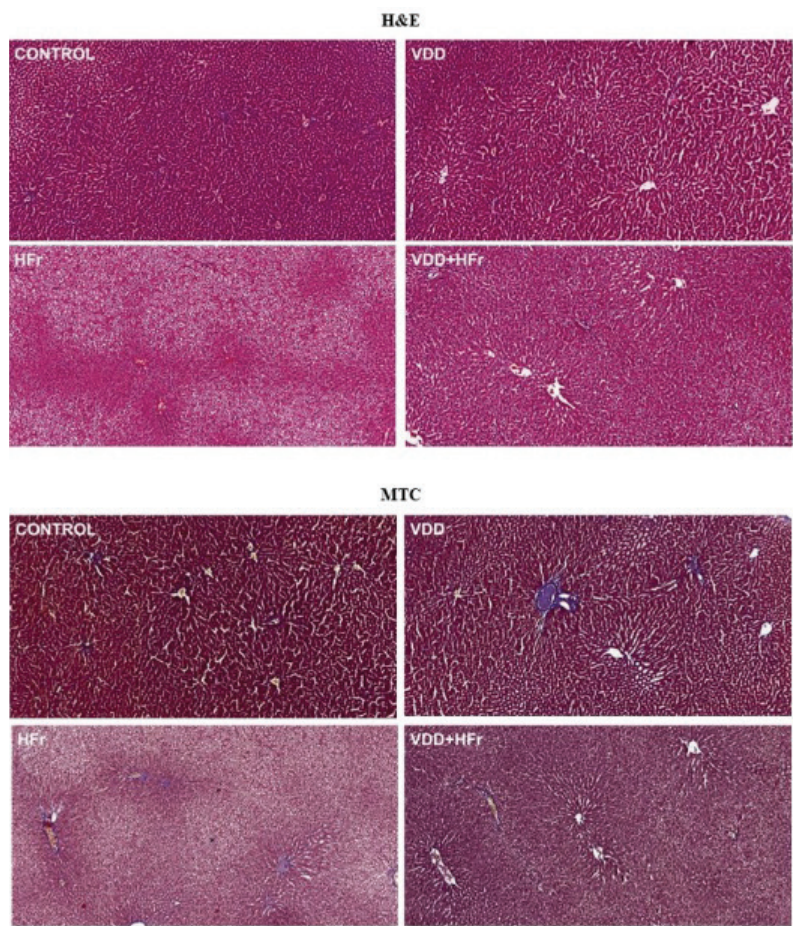

Figure 1: The effect of vitamin $\mathrm{D}$ deficiency (VDD) on histopathological changes in liver tissues of high fructose (HFr)-treated rats (H\&E and MTC, $\times 100$ )
VDD+HFr groups as compared to the control. TNF- $\alpha$ levels and MPO activity, but not TG and Hyp levels were higher in the VDD+HFr group than the HFr group (Figure 2).
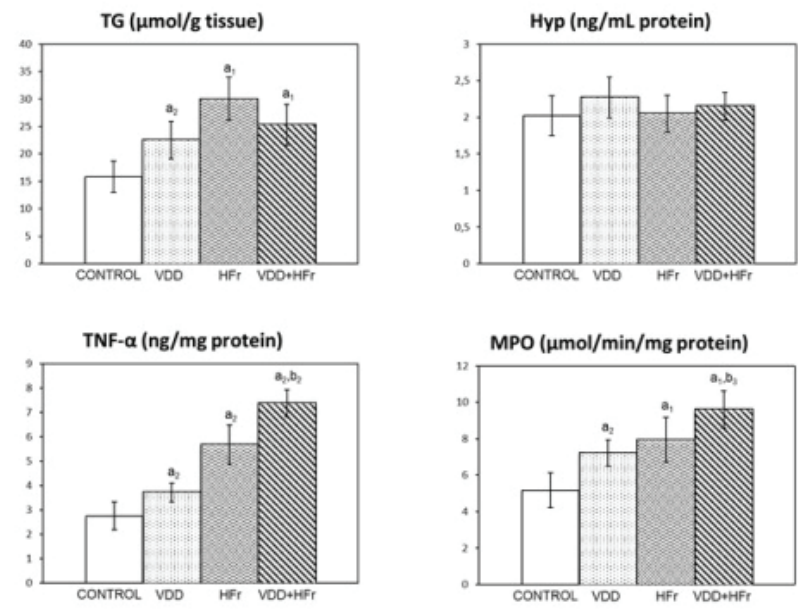

Figure 2. The effect of vitamin D deficiency (VDD) on hepatic triglyceride (TG), hydroxyproline (Hyp), tumor necrosis factor-alpha (TNF- $\alpha$ ) levels and myeloperoxidase (MPO) activities in high fructose (HFr)-treated rats (Mean \pm SD). ${ }^{a 1} p<0.001,{ }^{a 2} p<0.01,{ }^{a} p<0.05$ as compared to control; ${ }^{b 1} p<0.001,{ }^{b 3} p<0.05 \mathrm{HFr}$ vs $\mathrm{VDD}+\mathrm{HFr}$

Hepatic ROS, TBARS, DC and PC levels were elevated in both groups. However, the TBARS levels were higher in the VDD+HFr group than the HFr group (Figure 3). Hepatic AGEs and AOPP together with serum AGE and $\mathrm{CML}$ levels were increased in the $\mathrm{HFr}$ and $\mathrm{VDD}+\mathrm{HFr}$ groups as compared to the control (Table 3).

There were no changes in FRAP and GSH levels in the $\mathrm{HFr}$ and VDD+HFr groups. Hepatic SOD and GSH-Px activities diminished significantly, but CAT activity did not alter in the HFr group as compare to the control. The VDD+HFR and control groups did not differ in terms of antioxidant enzymes activities. When the HFr and VDD+HFr 
groups were compared, increases in SOD (30.8\%), GSH$\mathrm{Px}(16.6 \%)$ and CAT (20.7\%) activities were increased in the VDD+HFr group. However, increases in GSH-Px and CAT activities were not significant (Table 4).

mRNA expressions of Nrf2, SOD, GSH-Px, and CAT were decreased in the HFr group. In the VDD+HFr group,
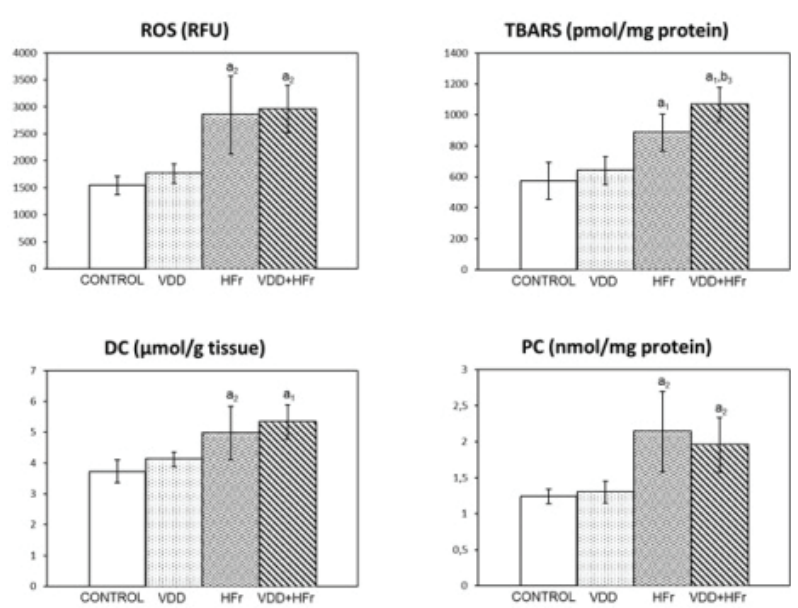

Figure 3. The effect of vitamin D deficiency (VDD) on hepatic reactive oxygen species (ROS), thiobarbituric acid reactive substances (TBARS), diene conjugates (DC) and protein carbonyl (PC) levels in high fructose (HFr)-treated rats (Mean $\pm S D$ ). ${ }^{a 1} p<0.001,{ }^{a 2} p<0.01$ as compared to control; ${ }^{b 3} \mathrm{p}<0.05$ HFr vs VDD+HFr
mRNA expression of SOD increased significantly as compared to the control, and Nrf2 and GSH-Px mRNA expressions returned to control levels. However, Nrf2, SOD and GSH-Px expressions were significantly higher than the HFr group. mRNA expression of CAT did not alter among the groups (Figure 4).
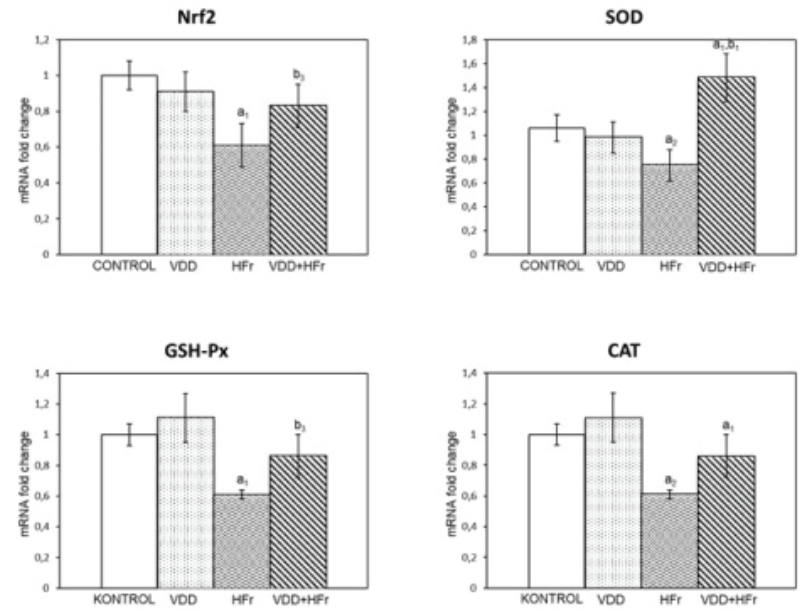

Figure 4. The effect of vitamin D deficiency (VDD) on hepatic mRNA expressions of nuclear erythroid factor 2-related factor (Nrf2) superoxide dismutase (SOD), glutathione peroxidase (GSH-Px) and catalase (CAT) in high fructose (HFr)-treated rats (Mean $\pm S D$ ). ${ }^{a 1} p<0.001,{ }^{a 2} p<0.01$ as compared to control; ${ }^{b 1} \mathrm{p}<0.001,{ }^{b 3} \mathrm{p}<0.05 \mathrm{HFr}$ vs $\mathrm{VDD}+\mathrm{HFr}$

Table 3: The effect of vitamin D deficiency (VDD) on serum advanced glycation end products (AGE) and carboxymethyllysine (CML) levels as well as hepatic advanced oxidized protein products (AOPP) and AGE in high fructose (HFr)-treated rats (Mean \pm SD)

\begin{tabular}{lcccc}
\hline & $\begin{array}{c}\text { Control } \\
(\mathbf{n}=6)\end{array}$ & $\begin{array}{c}\text { VDD } \\
(\mathbf{n}=\mathbf{8})\end{array}$ & $\begin{array}{c}\text { HFr } \\
(\mathbf{n}=7)\end{array}$ & $\begin{array}{c}\text { VDD+HFr } \\
(\mathbf{n}=\mathbf{8})\end{array}$ \\
Serum AGE $(\mathrm{RFU})$ & $186.3 \pm 15.4$ & $185.1 \pm 17.3$ & $250.6 \pm 29.8^{\mathrm{a} 1}$ & $260.5 \pm 17.6^{\mathrm{a} 1}$ \\
Hepatic AGE $(\mathrm{RFU})$ & $351.3 \pm 18.1$ & $330.5 \pm 20.7$ & $549.5 \pm 22.8^{\mathrm{a} 2}$ & $589.5 \pm 82.4^{\mathrm{a} 2}$ \\
Hepatic AOPP $(\mathrm{nmol} / \mathrm{mg}$ protein) & $22.8 \pm 0.96$ & $24.5 \pm 1.89$ & $28.7 \pm 3.02^{\mathrm{a} 1}$ & $30.6 \pm 2.46^{\mathrm{a} 1}$ \\
Serum CML $(\mu \mathrm{g} / \mathrm{L})$ & $12.3 \pm 1.75$ & $13.7 \pm 4.35$ & $17.34 \pm 3.00^{\mathrm{a} 3}$ & $16.9 \pm 1.20^{\mathrm{a} 3}$ \\
\hline
\end{tabular}

${ }^{a 1} p<0.001,{ }^{a 2} p<0.01,{ }^{a 3} p<0.05$ as compared to control

Table 4: The effect of vitamin D deficiency (VDD) on hepatic ferric reducing antioxidant power (FRAP), and glutathione (GSH) levels as well as hepatic superoxide dismutase (SOD), glutathione peroxidase (GSHPx), and catalase (CAT) activities in high fructose (HFr)-treated rats (Mean \pm SD)

\begin{tabular}{lcccc}
\hline & $\begin{array}{c}\text { Control } \\
(\mathbf{n}=\mathbf{6})\end{array}$ & $\begin{array}{c}\text { VDD } \\
(\mathbf{n}=\mathbf{8})\end{array}$ & $\begin{array}{c}\text { HFr } \\
(\mathbf{n}=\mathbf{7})\end{array}$ & $\begin{array}{c}\text { VDD+HFr } \\
(\mathbf{n}=\mathbf{8})\end{array}$ \\
FRAP ((nmol/mg protein) & $80.3 \pm 11.9$ & $76.9 \pm 15.8$ & $65.6 \pm 12.4$ & $77.5 \pm 11.8$ \\
GSH (nmol/mg protein) & $23.9 \pm 3.02$ & $24.0 \pm 6.30$ & $19.4 \pm 4.02$ & $17.3 \pm 4.16$ \\
SOD (U/mg protein) & $20.1 \pm 2.89$ & $18.7 \pm 1.43$ & $16.4 \pm 1.78^{\mathrm{a} 3}$ & $21.47 \pm 2.98^{\mathrm{b} 2}$ \\
GSH-Px (nmol/min/mg protein) & $520.9 \pm 64.1$ & $433.0 \pm 71.9$ & $383.7 \pm 32.5^{\mathrm{a} 2}$ & $447.4 \pm 60.5$ \\
CAT ( $\mu \mathrm{mol} / \mathrm{min} / \mathrm{mg}$ protein) & $352.6 \pm 47.7$ & $366.3 \pm 76.2$ & $314.4 \pm 36.4$ & $379.4 \pm 44.7$ \\
\hline
\end{tabular}

${ }^{a} \mathrm{p} p<0.01,{ }^{a} \mathrm{p} p<0.05$ as compared to control, ${ }^{\mathrm{b} 2} \mathrm{p}<0.01 \mathrm{HFr}$ vs $\mathrm{VDD}+\mathrm{HFr}$ 
In the VDD group, there were significant decreases in serum $25(\mathrm{OH}) \mathrm{D}_{3}$ and TG levels and significant increases in glucose and HOMA values as compared to the controls. In addition, hepatic TG and TNF- $\alpha$ levels and MPO activity were also increased. There were no changes in oxidative stress and protein glycation parameters and histopathological findings remained unchanged.

\section{DISCUSSION}

Several dietary models such as high fat, HFr, westernand methionine choline deficiency are used to produce NAFLD/NASH (4). Some investigators have reported that the HFr diet resulted in increased oxidative stress, increases in cytokines and AGEs levels in serum and liver (32-36). This diet caused hepatic lesions such as fatty liver, hepatocyte ballooning and lobular inflammation (32-36). Therefore, in this study, the role of the VDD diet in the pathogenesis of NAFLD was investigated by examining hepatic glycooxidative stress, inflammation and histopathology together with IR in a HFr-induced NAFLD model.

In the current study, rats received 30\% fructose containing drinking water for eight weeks as previously reported $(35,36)$. Prooxidant status was evaluated by determining ROS, oxidation products of lipids (TBARS and DC) and proteins (PC and AOPP). AGEs are heterogenous products, and fluorescent $A G E s$ and non-fluorescent $C M L$ levels were determined as protein glycation indicators (6). AOPP was reported to have some homologies with AGEs and to reflect protein glycooxidation (37). Determinations of TNF- $\alpha$ levels and MPO activity were used to examine hepatic inflammation. According to our results, the HFr diet caused IR, hypertriglyceridemia, increases in glycooxidative stress and inflammation together with histopathological changes (marked microvesicular steatosis, hepatocyte ballooning and no fibrosis) in rats. These findings indicate that the hepatic lesions were produced successfully in the HFr-induced NAFLD model.

Nrf2 is a transcription factor that is the main regulator of the antioxidant system. It regulates redox homeostasis by increasing the expression of many antioxidant enzymes such as SOD, GSH-Px, and CAT and plays a key role in combating oxidative stress $(12,14)$. The antioxidant potential of $1,25(\mathrm{OH})_{2} \mathrm{D}_{3}$ is related to its direct antioxidant potential and the upregulation of $\mathrm{Nrf} 2$ and its target antioxidant genes $(8,12,14,38)$. It has a suppressive effect against oxidative stress in dietary NAFLD models due to these properties (39-41).

On the other hand, VDD was reported to have an additional effect in the experimental dietary model of NAFLD as a second hit (42-45). However, some contradictory results are also available $(46,47)$. VDD diet exacerbated high fat diet (HFD)- $(42,43)$ or HFD+HFr $(44)$-induced metabolic changes and progressed NAFLD into NASH by increasing IR, inflammation and lipogenesis and decreasing $\beta$-oxidation. Similarly, long term feeding of VDD plus HFr-diet was reported to cause progression of NAFLD into NASH by increasing hepatic steatosis, inflammatory lesions and interstitial fibrosis (45). Contrarily, VDD alleviated HFD-induced overweight, hyperinsulinemia, and hepatic steatosis through promoting fatty acid $\beta$-oxidation (46). It has also been reported that there was no difference between HFr and VDD+HFr groups in terms of inflammation, steatosis and expressions of genes related to lipogenesis and $\beta$-oxidation (47). However, there is not enough information about how VDD affects glycooxidative stress and antioxidant system parameters in dietary NAFLD models. For this reason, this subject was focused on in our study.

Serum $25(\mathrm{OH}) \mathrm{D}$ levels were reported as $27-30 \mathrm{ng} / \mathrm{ml}$ in normal mice fed on standard rodent chow containing Vit $D_{3}(1,500 \mathrm{lU} / \mathrm{kg})$. In the same study, it was reported that the administration of a diet containing low doses of Vit $D_{3}$ (50 and $250 \mathrm{IU} / \mathrm{kg}$, respectively) resulted in serum 25(OH)D levels compatible with severe VDD and VDD, respectively, as early as four weeks, and these levels were maintained for 3-4 months (48). Therefore, in our study, $\mathrm{HFr}$ drinking was started four weeks after VDD diet application and continued for eight weeks and then serum $\mathrm{Vit}$ $(\mathrm{OH}) \mathrm{D}$ levels were found between $10-20 \mathrm{ng} / \mathrm{ml}$ in rats fed on a diet to which $V$ it $D_{3}$ is not added (48).

Some authors have reported that VDD diet alone resulted in moderate steatosis, inflammation, IR together with upregulation of genes related to lipogenesis and inflammation in the liver of rodents $(43,47)$. However, some investigators have found that there were no changes in metabolic parameters and liver damage markers due to a VDD diet (46). There is limited knowledge about prooxidant-antioxidant status due to $\operatorname{VDD}(49,50)$. In this study, the VDD diet alone was observed not to alter hepatic prooxidant-antioxidant balance, mRNA expressions of $\mathrm{Nrf2}$ and antioxidant enzymes, protein glycation parameters and histopathological findings despite increased inflammation, liver TG levels and IR.

In this study, when VDD and HFr diets were combined, the VDD diet did not augment HFr-induced oxidative stress, protein glycation, and hepatic damage. However, IR and inflammation parameters were higher in the VDD+HFr group than HFr. There was no difference in GSH and FRAP levels and CAT activity between the $\mathrm{VDD}+\mathrm{HFr}$ and HFr groups. Although SOD and GSH-Px activities decreased in the HFr group, these activities returned to normal in the VDD+HFr group. This situation may be related to increases in gene expressions of these enzymes. Indeed, interestingly, Nrf2, SOD and GSH-Px mRNA expressions were significantly higher in the VD$\mathrm{D}+\mathrm{HFr}$ group than the HFr group. These changes in the 
antioxidant system may provide a protection against an additional increase in prooxidant status and HFr-induced liver damage in the VDD+HFr group.

\section{CONCLUSION}

Our results indicate that VDD augmented HFr-induced insulin resistance and hepatic inflammation, and upregulated Nrf2 and antioxidant enzymes while exhibiting no change in glycooxidative stress and histopathological changes. These results suggest that more studies are necessary to elucidate the effect of VDD on NAFLD progression.

Ethics Committee Approval: This study was approved by The Animal Care and Use Committee of the University of Istanbul (Date: 29.03.2018, No: 2108/28).

Peer Review: Externally peer-reviewed.

Author Contributions: Conception/Design of Study- I.B., M.U.; Data Acquisition- I.B., C.K., A.F.A., I.D.E.; Data Analysis/Interpretation- I.B., S.D.A., M.U.; Drafting Manuscript- I.B., M.U; Critical Revision of Manuscript- A.F.A., S.D.A.; Final Approval and Accountability- I.B. ,C.K.,A.F.A.,I.D.E.,S.D.A.,M.U.

Conflict of Interest: Authors declared no conflict of interest.

Financial Disclosure: The present work was supported by The Research Fund of Istanbul University (Project Number: TSA2018-30443).

Etik Komite Onayı: Bu çalışma için etik komite onayı İstanbul Üniversitesi Hayvan Deneyleri Etik Kurulu'ndan alınmıştır (Tarih: 29.03.2018, No: 2108/28).

Hakem Değerlendirmesi: Dış bağımsız.

Yazar Katkıları: Çalışma Konsepti/Tasarım- I.B., M.U.; Veri ToplamaI.B., C.K., A.F.A., I.D.E.; Veri Analizi/Yorumlama- I.B., S.D.A., M.U.; Yazı Taslağı: I.B., M.U; İçeriğin Eleştirel İncelenmesi- A.F.A., S.D.A.; Son Onay ve Sorumluluk- I.B., C.K., A.F.A., I.D.E., S.D.A., M.U.

Çıkar Çatışması: Yazarlar çıkar çatışması beyan etmemişlerdir.

Finansal Destek: Bu çalışma İstanbul Üniversitesi Bilimsel Araştırma Projeleri Koordinasyon Birimi tarafından ile desteklenmiştir (Proje Numarası: TSA-2018-30443).

\section{REFERENCES}

1. Ibrahim MA, Kelleni M, Geddawy A. Nonalcoholic fatty liver disease: Current and potential therapies. Life Sci 2013;92(2):114-8. [CrossRef]

2. Fernando DH, Forbe JM, Angus PW, Herath CB. Development and progression of non-alcoholic fatty liver disease: The role of advanced glycation end products. Int J Mol Sci 2019;20(20):5037. [CrossRef]

3. Alwahsh SM, Gebhardt R. Dietary fructose as a risk factor for non-alcoholic fatty liver disease (NAFLD). Arch Toxicol 2017;91(4):1545-63. [CrossRef]
4. Takahashi Y, Soejima Y, Fukusato T. Animal models of nonalcoholic fatty liver disease/nonalcoholic steatohepatitis. World J Gastroenterol 2012;18(19):2300-8. [CrossRef]

5. Jegatheesan P, De Bandt JP. Fructose and NAFLD: Multifaceted aspects of fructose metabolism. Nutrients 2017;9(3):230. [CrossRef]

6. Gugliucci A. Formation of fructose-mediated advanced glycation end products and their roles in metabolic and inflammatory diseases. Adv Nutr 2017;8(1):54-62. [CrossRef]

7. Kwok RM, Torres DM, Harrison SA. Vitamin D and nonalcoholic fatty liver disease (NAFLD): Is it more than just an association? Hepatology 2013;58(3):1166-74. [CrossRef]

8. Uberti F, Morsanuto V, Molinari C. Vitamin D in oxidative stress and diseases. 'A Critical Evaluation of Vitamin D-Basic Overview. Ed: Sivakumar Joghi Thatha Gowder, IntechOpen, Chapter 2, pp 47-73. 2017. [CrossRef]

9. Kheirouri S, Alizadeh M. Vitamin D and advanced glycation end products and their reseptors. Pharmacol Res 2020;158:104879. [CrossRef]

10. Khan S, Ali A, Khan S, Bakillah A, Damanhouri G, Khan A, et al. Current therapies in alleviating liver disorders and cancers with a special focus on the potential of vitamin $D$. Nutr Metab 2018;15:13. [CrossRef]

11. Eliades M, Spyrou E. Vitamin D: A new player in nonalcoholic fatty liver disease? World J Gastroenterol 2015;21(6):1718-27. [CrossRef]

12. Berridge MJ. Vitamin D signalling in health and disease. Biochem Biophys Res Commun 2015;460(1):53-71. [CrossRef]

13. Wang $H$, Chen W, Li D, Yin X, Zhang $X$, Olsen N, et al. Vitamin D and chronic diseases. Aging Dis 2017;8(3):346-53. [CrossRef]

14. Wimalawansa SJ. Vitamin D deficiency: Effects on oxidative stress, epigenetics, gene regulation and aging. Biology 2019;8(2):30-45. [CrossRef]

15. Institute of Medicine. Dietary references intakes for calcium and vitamin D. Eds: Ross AC, Taylor CL, Yaktine AL, Del Valle HB, Washington-DC, National Academies Press (US), 2011.

16. Elangovan H, Chahal S, Gunton JE. Vitamin D in liver disease: Current evidence and potential directions. Biochim Biophys Acta 2017;1863(4):907-16. [CrossRef]

17. Karatayli E, Stokes CS, Lammert F. Vitamin D in preclinical models of fatty liver disease. Anticancer Res 2020;40(1): 527-34. [CrossRef]

18. Rachmilewitz D, Stamler JS, Karmeli F, Mullins ME, Singel DJ, Loscalzo J, et al. "Peroxynitrite-induced rat colitis - a new model of colonic inflammation". Gastroenterology 1993;105(6):1681-8. [CrossRef]

19. Wang $H$, Joseph JA. Quantifying cellular oxidative stress by dichlorofluorescein assay using microplate reader. Free Radic Biol Med 1999;27(5-6):612-6. [CrossRef]

20. Buege JA, Aust SD. Microsomal lipid peroxidation. Methods Enzymol 1978;52:302-10. [CrossRef]

21. Reznick $A Z$, Packer L. Oxidative damage to proteins: spectrophotometric method for carbonyl assay. Methods Enzymol 1994;233:357-63. [CrossRef]

22. Hanasand M, Omdal R, Norheim KB, Gøransson LG, Brede C, Johnson G. Improved detection of advanced oxidation protein products in plasma. Clin Chim Acta 2012;413(910):901-6. [CrossRef] 
23. Münch $G$, Keis R, Wessels A, Riederer P, Bahner U, Heidland $A$, et al. Determination of advanced glycation end products in serum by fluorescence spectroscopy and competitive ELISA. Eur J Clin Chem Clin Biochem 1997;35(9):669-77. [CrossRef]

24. Benzie IFF, Strain JJ. The ferric reducing ability of plasma (FRAP) as a measure of 'antioxidant power": the FRAP assay. Anal Biochem 1996;239(1):70-6. [CrossRef]

25. Beutler E, Duron O, Kelly BM. Improved method for the determination of blood glutathione. J Lab Clin Med 1963;61:882-8.

26. Mylorie AA, Collins H, Umbles C, Kyle J. Erythrocyte superoxide dismutase activity and other parameters of copper status in rats ingesting lead acetate. Toxicol Appl Pharmacol 1986;82(3):512-20. [CrossRef]

27. Lawrence RA, Burk RF. Glutathione peroxidase activity in selenium deficient rat liver. Biochem Biophys Res Commun 1976;425(3):503-9. [CrossRef]

28. Worthington V. Catalase. In: Worthington Enzyme Manuel: Enzymes and related biochemicals. New Jersey: Worthington Biochemical Corporation, pp.77-80, 1993.

29. Smith PK, Krohn RI, Hermanson GT, Mallia AK, Gartner $\mathrm{FH}$, Provenzano MD, et al. Measurement of protein using bicinchoninic acid. Anal Biochem 1985;150(1):76-85. [CrossRef]

30. Goodman ZD. Grading and staging systems for inflammation and fibrosis in chronic liver diseases. J Hepatol 2007;47(4):598-607. [CrossRef]

31. Bingül I, Aydın AF, Başaran-Küçükgergin C, Doğan-Ekici I, Çoban J, Doğru-Abbasoğlu S, et al. High-fat diet plus carbon tetrachloride-induced liver fibrosis is alleviated by betaine treatment in rats. Int Immunopharmacol 2016;39:199-207. [CrossRef]

32. Bagul PK, Middela H, Matapally S, Padiya R, Bastia T, Madhusudana $K$, et al. Attenuation of insulin resistance, metabolic syndrome and hepatic oxidative stress by resveratrol in fructose-fed rats. Pharmacol Res 2012:66(3):260-8. [CrossRef]

33. Giriş $M$, Doğru-Abbasoğlu $S$, Kumral A, Olgaç V, KoçakToker N, Uysal M. Effect of carnosine alone or combined with $\alpha$-tocopherol on hepatic steatosis and oxidative stress in fructose-induced insulin-resistant rats. J Physiol Biochem 2014;70(2):385-95. [CrossRef]

34. Li W, Lu, Y. Hepatoprotective effects of sophoricoside against fructose-induced liver injury via regulating lipid metabolism, oxidation, and inflammation in mice. J Food Sci 2018;83(2):552-8. [CrossRef]

35. Yang Y, Wang J, Zhang Y, Li J, Sun W. Black sesame seeds ethanol extract ameliorates hepatic lipid accumulation, oxidative stress, and insulin resistance in fructose-induced nonalcoholic fatty liver disease. J Agric Food Chem 2018;66(40):10458-69. [CrossRef]

36. Pai SA, Munshi RP, Panchal FH, Gaur IS, Juvekar AR. Chrysin ameliorates nonalcoholic fatty liver disease in rats. NaunynSchmiedeberg's Arch Pharmacol 2019;392(12):1617-28. [CrossRef]
37. Capeillere-Blandin C, Gausson V, Descamps -Latscha B, Witko-Sarsat V. Biochemical and spectrophotometric significance of advanced oxidized protein products. Biochim Biophys Acta 2004;1689(2):91-102. [CrossRef]

38. Mokhtari Z, Hekmatdoost A, Nourian M. Antioxidant efficacy of vitamin D. J Parathyroid Dis 2017;5(1):11-6.

39. Zhu CG, Liu YX, Wang H, Wang BP, Qu HQ, Wang BL, et al. Active form of vitamin $D$ ameliorates non-alcoholic fatty liver disease by alleviating oxidative stress in a high-fat diet rat model. Endocr J 2017;64(7):663-73. [CrossRef]

40. Liu Y, Wang M, Xu W, Zhang H, Qian W, Li X, et al. Active vitamin $D$ supplementation alleviates and progression of non-alcoholic liver disease by repressing the p53 pathway. Life Sci 2020;241:117086. [CrossRef]

41. Ma M, Long Q, Chen F, Zhang T, Wang W. Active vitamin D impedes the progression of non-alcoholic cell senescence in a rat model. Clin Res Hepatol Gastroenterol 2020;44(4):51323. [CrossRef]

42. Kong M, Zhu L, Bai L, Zhang X, Chen Y, Liu S, et al. Vitamin D deficiency promotes nonalcoholic steatohepatitis through impaired enterohepatic circulation in animal model. Am J Physiol Gastrointest Liver Physiol 2014;307(9):G883-G893. [CrossRef]

43. Su D, Nie Y, Zhu A, Chen Z, Wu P, Zhang L. et al. Vitamin $D$ signaling through induction of paneth cell defensins maintains gut microbiota and improves metabolic disorders and hepatic steatosis in animal models. Front Physiol 2016;7:498. [CrossRef]

44. Roth CL, Elfers CT, Figlewicz DP, Melhorn SJ, Morton GJ, Hoofnagle $A$, et al. Vitamin $D$ deficiency in obese rats exacerbates nonalcoholic fatty liver disease and increases hepatic resistin and Toll-like receptor activation. Hepatology 2012;55(4):1103-11. [CrossRef]

45. Li W, Zhang L, Liu Y, Wang C, Long Y, Huang Z, et al. Metabolite profiling of mice under long-term fructose drinking and vitamin $D$ deficiency: increased risks for metabolic syndrome and nonalcoholic fatty liver disease. J Physiol Biochem 2020;76(4):587-98. [CrossRef]

46. Liu XJ, Wang BW, Zhang C, Xia MZ, Chen YH, Hu CQ, et al. Vitamin $D$ deficiency attenuates high-fat diet-induced hyperinsulinemia and hepatic lipid accumulation in male mice. Endocrinology 2015;156(6):2103-13. [CrossRef]

47. Maia-Ceciliano TC, Dutra RR, Aguila MB, Mandarim-DeLacerda CA. The deficiency and the supplementation of vitamin $D$ and liver: Lessons of chronic fructose-rich diet in mice. J Steroid Biochem Mol Biol 2019;192:105399. [CrossRef]

48. Mallya SM, Corrado KR, Saria EA, Yuan FNF, Tran HQ, Saucier K, et al. Modeling vitamin D deficiency and moderate deficiency in adult mice via dietary cholecalciferol restriction. Endocrin Res 2016;41(4):290-9. [CrossRef]

49. Bhat $M$, Ismail $A$. Vitamin $D$ treatment protects against and reverses oxidative stress induced muscle proteolysis. J Steroid Biochem Mol Biol 2015;152:171-9. [CrossRef]

50. Tao S, Yuan Q, Mao L, Chen FL, Ji F, Cui ZH. Vitamin D deficiency causes insulin resistance by provoking oxidative stress in hepatocytes. Oncotarget 2017;8(40):67605-13. [CrossRef] 